I IUC STUDI ES

ISSN 1813-7733

Vol. - 3, December 2006 (p 83-92)

\title{
Informal Islamic Education and its Role in Human Resource Development in Society: A Theoretical Evaluation
}

\author{
Kamiz Uddin Ahmed Alam* \\ Mohammad Aman Uddin Muzahid**
}

\begin{abstract}
This article attempts to focus on Islamic education in the informal setting, its correspondence with human resource development and the role of this development to create a sound and balanced environment in society with moral and spiritual values. Firstly, the paper addresses education and its function in general and then education from Islamic perspective. Secondly, it discusses the character of informal Islamic education, the role players of the field of informal Islamic education, their status as teachers, the role of a teacher, the competencies of a teacher, and teacher - learner relationship in the light of Islamic culture and heritage. Finally, a proposal on the specific subject of Informal Islamic education and the strategies of imparting it are presented in the article.
\end{abstract}

\section{Introduction:}

Education enlightens people on culture and values. Islam has its own attitude towards education that education is the instrument by which people can be trained in the Islamic way of life. It aims at producing human resources following the Islamic teachings especially spirituality and morality. The target can be materialised through the different channels of education, i.e., formal, non-formal and informal. So, Islamic education in the informal process is not negligible and its role deserves to be considered significant comparing with that of formal Islamic education. We observe that while formal Islamic education is imparted, teachers and institutes are engaged and the methodology is applied, but no technique is usually applied for presenting Islamic teachings though in society a great number of people with their missionary zeal are dedicated to imparting these in the informal way. However, these people have the opportunities to apply the teaching methodology and technique to carry out their noble duties effectively. Considering this, the paper emphasises the status of the role players of informal Islamic education, methodologies and techniques and the certain aspects of this process of teaching to be followed by them for developing human resource that surely can play an important role to build a healthy environment in society.

\section{Explanation of Paradigms}

a) Education:

Education is a social function. Thus it serves the society which maintains it. Its first and foremost role is to conserve the existing culture [and values], by transmitting it from generation to generation. But an equally important role is to renovate this culture so that it may keep pace with changing times. As a cultural undertaking, education is, therefore,

* Lecturer of the Department of English Language and LIterature, Darul Ihsan University, Dhaka, Bangladesh. E-mail: raiha_diu@yahoo.com.

** Assistant Director, STAD, IIUC, Dhaka Campus and Ph.D researcher under the Department of Islamic Studies, Dhaka University. E-mail: amanmuzahid@yahoo.com 


\section{IIUC Studies, Vol. 3}

not only an instrument of social stability, but also an agent of social change. In both of its two roles, it serves one purpose: continuity and growth of society. A society must be stable enough to give us a foothold in the world of perpetual change and yet at the same time, it must be flexible enough to adapt itself to changing needs of the time. However, stable a society might be, it cannot rule out the possibility of change in its cultural traditions; if it does, it becomes static and loses not only its vigor, but also its hold and is finally wiped out of existence. ${ }^{1}$

Education is a process by which men and women, young and old, are taught how to contribute to their own welfare and the welfare of the society to which they belong. It prepares them for playing their role in society adequately. In Platonic terminology, education is the training of each individual to do, for what his talents peculiarly suit, in such a way as to benefit the whole social group. ${ }^{2}$

\section{b) Education and Islam:}

In Islamic perspective the principle of education is that the recognition and acknowledgement of the proper places of things in order of creation so that it leads to the recognition and acknowledgement of the proper place of God and His existence. ${ }^{3}$ Through education man must know his place in human order that is his station and condition in life in relation to his self, his family, his people, his community, and his society. He must know the relationship between creations and creator applying the Qur'ānic criteria of intelligence, knowledge and virtue. ${ }^{4}$ According to Islam, education is the device for enabling an individual to attain full stature and realize his nature, which is divine. It would be realization to become all he has the capacity to be. This was due to this importance of education in Islam that the Muslims established an exemplary system of Islamic education. ${ }^{5}$

It is clear from the various Western theories of education that the West has utilitarian and materialistic emphases, while in Islam seeking knowledge is the duty of every Muslim, a form of Islamic worship for the betterment of this world and the hereafter. ${ }^{6}$

Islamic educational terms, tarbiyah, ta'lim and tadib, taken together convey the meaning and scope of education in Islam, both formal and non-formal [and informal, also]. ${ }^{7}$

The Arabs used the word ta'dib meaning "refinement or discipline" for what we call education. They called an educator as muaddib (one who refines or teaches manners). In Arabic, the word tarbiyah (education) is derived from the root raba-yarbu meaning to grow or increase. Hence, education means gradual bringing of something to completeness, perfection or maturity. ${ }^{8}$

\section{c) Informal Islamic Education:}

Informal education is different from both formal and non-formal education. Informal education is the life long-process by which everybody acquires knowledge, skills, attitudes and insights from daily experiences at home, at work, at play whereas formal education is highly institutionalised, chronologically graded, and well structured education system, and non-formal education is generally defined as any organized and systematic educational activity carried on outside framework of the formal education system to provide selected types of learning to particular sub-groups in the population. Besides, informal education is generally unorganised and often unsystematic. ${ }^{9}$ Therefore, Islamic teachings and values that have been imparted to people traditionally (not institutionally) for generation after generation in the communicative approach are informal Islamic education. 


\section{Informal Islamic Education and its Role in Human Resource Development in Society}

Islam starts its very journey with informal education from the first Prophet Hazrat Adam (As) to the last Prophet Hazrat Mohammad (Sm.). The Prophet's (Sm.) teaching people from Darul Arkam in Mecca to Masjid-e-Nababi and Ahle-Suffa in Madina and his last public speech at Arafat imparted education which was informal education. Every day activities of the Prophet (Sm.) still alive education for his followers. And Islam was preached in different continents through informal education. Still today it can play a vital role in Muslim society in bringing back its past glory as well as coping with the modern age.

Informal education is an immense need in our present society if we consider the following realities:

a) A large number of people are still illiterate (50\%).

b)Even in formal channels, Islamic education is not equally accessible to all.

c) There is the lack of concepts of Islam even amongst the educated Muslims. ${ }^{10}$

Islam is a practical religion in which Shari' $\bar{h}$ is based on the oneness and greatness of Allah and Prophethood. It would be necessary to remind ourselves of the main elements of Islamic moral education, either formal or informal education. These elements are:

a) The teaching of substantive moral judgments which are taken from Shari'āh and which are binding on all Muslims.

b) The cultivation of rationality, awareness and moral understanding.

c) The creation of a healthy environment in society to allow people to discipline themselves practically into a moral framework. This can he done by creating contexts and activities through which moral education can be achieved. ${ }^{11}$

\section{The Role Players of Informal Islamic Education:}

Mosques and Imams, Preachers, Islamic Donors and Social Workers (NGO's), Media, Teachers, Conscious Writers and Cultural Activists and Local Government are absolutely able to impart informal Islamic education all over the Muslim World. ${ }^{12}$ All of them can be generalized as teachers, and if they function accordingly, they all deserve the status ensured by Islam to teachers. And the Muslims irrespective of literate, illiterate, man, woman, professional, nonprofessional, young and old can be regarded as learners of informal Islamic education throughout the life.

\section{a) Status of a Teacher:}

Teachers in the Islamic system enjoyed a unique status in the Muslim world [in its glorious era]. They presented a pattern of moral and social leadership, which has no parallel in the social structure of the modern world. The social gauge by which prestige of individuals could be measured was not so precise and simple as it today. ${ }^{13}$

In the Islamic society, teachers or ulama enjoy a high social status. We have seen how the first verse in the Qur'ān encouraged learning and teaching. Those who possess knowledge and teach it to others are exalted and respected by Islam. The Qur'ann says: $(58: 11)$

"God will exalt those of you who believe and those who are given knowledge to high degrees." 


\section{IIUC Studies, Vol. 3}

The Prophet (Sm) says:

"The learned ones are the heirs of the Prophets - they leave knowledge as their inheritance: he who inherits it inherits a great fortune."

In this saying the ulama or teachers are exalted by being described as the heirs of the Prophets. To show the importance of teachers, the stress in the saying is also on conveying or teaching knowledge to others and this knowledge is described as great fortune, indicating the worthwhile activities of the teachers. ${ }^{14}$

\section{b) The Role of a Teacher in Islam:}

In all ideological systems of education, specially the religious ones, it is the teacher who occupies the central position. ... As an heir of the Prophet, the Muslim teacher is the custodian of the cultural [and moral] values of Islam and that of the society which derives strength from them. He is responsible for preserving the cultural tradition by transmitting it from generation to generation and thus making the growth and continuity of society possible. ${ }^{15}$ His responsibility thus is two- fold: to preserve the existing cultural tradition; and to mobilise it, by bringing it into closer contact with its own original spirit and with the spirit of modern times. ${ }^{16}$ So, a teacher to impart Islamic education in informal channels, who has the opportunity to play his role from the grassroots to the upper class of the society, should be equipped with some essential competencies as well as the teacher-learner relationship.

\section{c) The Competencies of a Teacher:}

A Muslim teacher should be aware of certain competencies. We have to keep these characteristics in view while imparting informal Islamic education for ensuring its beneficial effects on society and also developing or organizing any programme of teacher training in the ummah. These are as follows:

- A Muslim teacher should comply with the Sharia'āh .

- A Muslim teacher should fear God.

- A Muslim teacher should possess sound personal character.

- A Muslim teacher should be a model for students in personality and character.

- A Muslim teacher should be kindhearted, gentle and lenient to students.

- A Muslim teacher should be dignified and solemn.

- A Muslim teacher should be a missionary.

- A Muslim teacher should teach with good motive.

- A Muslim teacher should be intellectually competent.

- A Muslim teacher must possess and transfer the Islamic vision. ${ }^{17}$

\section{d) Teacher-Learner Relationship:}

The teacher-pupil relationship in Islamic education was raised to such a level that Muslim teachers treated their sons and pupils alike. In most cases they did the fullest measure of justice to the intellect and ability of students and prized talented pupils more than their sons. Caliph Ali (R.A) rightly bestowed teachers the status of one of the three fathers of man, the other two being real father and the father-in-law. Teachers of the Muslim world were essentially loco parents for pupils and helped them with all the means at their 
disposal in pursuit of learning. Teachers even used to extend monetary help to needy students of their circle instead of receiving tuition fees from them. Imam Shafii was helped most generously by Imam Muhammad bin al-Hasan and even by Imam Maalik while the help rendered by Imam Abu Hanifa to his pupil Imam Abu Yusuf prevented him from giving up his studies. Qazi Ibn Furat received eighty diners from his teacher when he came to know that his student could not continue his studies with the money his family gave. ${ }^{18}$

\section{Informal Islamic Education and Human Resource Development:}

Human resource development is a process of helping people to acquire competencies. It is a process of increasing knowledge, skill and the capacity of people in society. From economic and political perspectives the concept of human resource development is viewed in different ways. From the social and cultural point of view, the development of human resources contributes to the enrichment of life. To Islam human development means the development of spiritual and human virtues. The Islamic perspective of education and human resource development corresponding to the three stages of human development is depicted in the following table. ${ }^{19}$

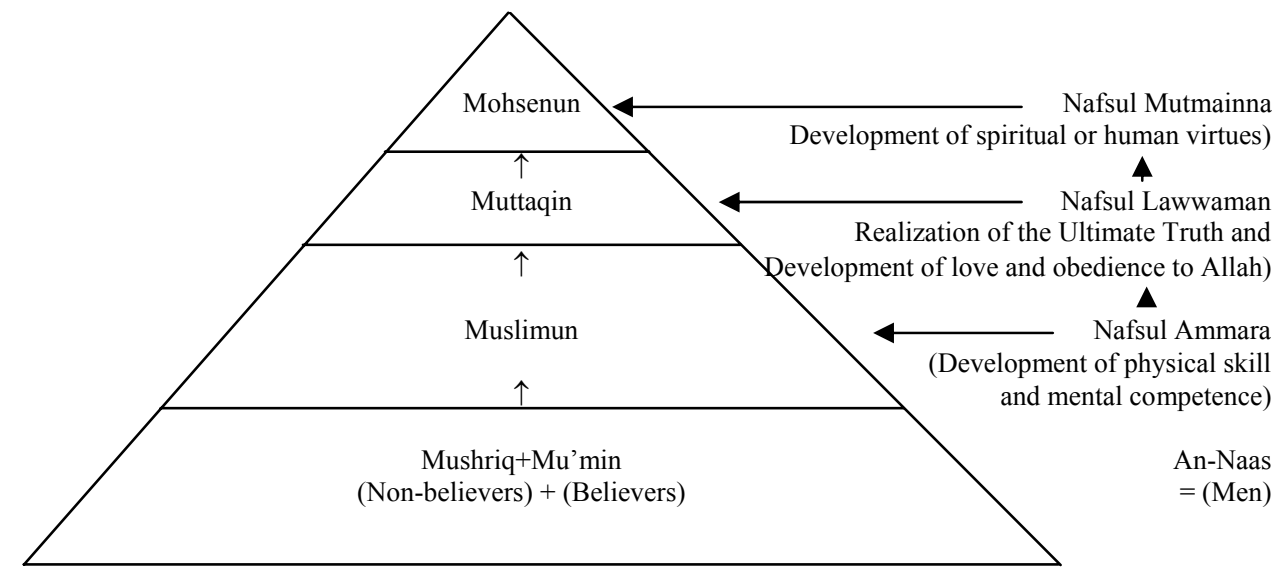

Table: Stages of Human Resource Development

In fact, Islam encourages its followers to achieve the highest degree of human virtue i.e. Ihsan that is also the root of Islamic spiritualism and morality. In Islamic moral teaching it is to be remembered that we will have to provide an account to the Almighty Allah on the Day of Judgment for all of our action on earth.(Qur'ān 2:281).Informal Islamic education aims at producing spiritually and ethically developed human beings. This Islamic perspective can effectively be imparted to the people of the society in the informal setting of Islamic education through its different ways and the people will be able to play the vital role to build a society being enriched with moral and spiritual values.

\section{a) Some important Aspects of Informal Islamic Education for Creating a Healthy Environment in Society:}

Society and individuals are reciprocally dependent. Individuals have the definite role to preserve their faith, culture and way of life in the society. They can build a society that will be really a place of peace and harmony and free from the different sorts of conflicts and chaos. To build such a society, the following aspects can be regarded as the subjects of informal Islamic education, and they should be presented to the people in the light of 


\section{IIUC Studies, Vol. 3}

Islam with the explanations of their social, religious, moral and spiritual functions:

- Teaching people regarding the accountability to Allah

- Teaching people to lead a disciplined Society

- Brotherhood

- The principles of humanity

- Taking decisions through consultation (Mushwarah)

- Sense of obedience

- Sense of sacrifice

- Justice

- Good behavior

- Forgiveness

- Reliability

- Respect and love

- Ensuring others rights

- Tolerance

- Calling for good and forbidding evil.

In addition to that one curriculum may be developed to impart informal Islamic education.

\section{b) Teaching Strategy:}

Informal education is practically based on communicative teaching method. Communicative teaching must be interactive in nature and must not become merely a matter of uninterrupted transmitter and receiver. 'The Grand Principles' of Communicative teaching is outlined in the Holy Qur'ān:

"Call to the way of your Lord with wisdom and beautiful preaching and argue with them with that which is best." (Qur'ān16:125)

The methodology has three distinct parts:

a) Application of wisdom: The teaching materials have to be judiciously chosen keeping in view, the learners' age, background, experience and qualification.

b) The materials have to be suitable and worthwhile.

c) Application of beautiful preaching i.e. exposition: For beauty of exposition the teachers of informal Islamic education have to consider the application of logic in teaching, the use of appropriate language and the importance of clear voice to impart Islamic education.

d)Application of the best possible way of arguing: The best possible method of arguing can be obtained only when the teacher attempts with care and patience, to answer as far as possible various queries that exist in the minds of the learners. 


\section{Informal Islamic Education and its Role in Human Resource Development in Society}

Incidentally, query is the basis of knowledge and the Holy Qur'ān does not discourage queries as long as the queries are made for the satisfaction of one's soul (Qur'ān 2:260). ${ }^{20}$

According to Alexander White, to transmit something three things i.e. greed, fear or curiosity will be created among the audience. ${ }^{21}$ According to Robert E. Slaving, effective instruction is an art of teaching that is sensitive to the content, the context and to the particular needs of students. There are many models and literature about effective instruction and one of them is the QAIT model recommended by Robert Slaving. QAIT stands for Quality of Instruction, Appropriate levels of Instruction, Incentive (teachers make sure that students are motivated to work on instructional tasks and learn the material presented) and Time (needed to meet the students' ability to comprehend the lesson or material presented). ${ }^{22}$

We have observed the Prophet's (Sm) rich methods of instructions guided by the Qur'ān. A brief summary of them can be categorized as follows:

- Story telling (primarily to derive lessons from stories of past)

- By example/modeling

- Stories of righteous

- Physical example

- Discussion using current event (taking advantage of current situation to stress a point)

- High morals

- Using concept of hope (or reward i.e., Paradise)

- Using concept of fear (or punishment i.e., Hellfire)

- Competition to attain goodness

- Speaking to people in the language they can understand (past knowledge/ experience is an important factor)

- Reaching a point step by step

- Sense of humour (without deviating from the truth or losing selfrespect)

- Duaa in front of a person

- Indirect instruction (to benefit all the audience and at the same time without embarrassing any particular person )

- Repetition

- Enumerating ( mention a number before delivering the point in order to prepare the audience on what to expect)

- Raising points by raising questions

- Rhythm (delivering advice in a rhythmic manner)

- Stressing on using preposition [connectors] to state an important fact (i.e., indeed, at the beginning of a point). ${ }^{23}$

It is vivid that no techniques of teaching Islamic materials would succeed unless the teacher has a good image amongst his audience. The techniques must be based on an 


\section{IIUC Studies, Vol. 3}

effective interaction between the teacher and the learner and should be focused on the involvement of people. The techniques should vary from learner to learner depending on the levels of their education and understanding. The techniques should also depend on the ways in which informal education is being imparted. The ways may include the following:

- Woaz

- Khutba

- Talk on Radio

- Talk on Television

- Seminar or Workshop

- Written materials

- Cultural Programmes. ${ }^{24}$

Though some of them have their association with formal education, they can be applied as the instruments of the informal process of Islamic education.

The people engaged in imparting informal Islamic education must apply the above methodology. They must be knowledgeable and thoughtful. Further, Informal Islamic education should be communicated in the most convenient way.

\section{Conclusion:}

In this article an attempt has been made to highlight the role of informal Islamic education to help build a healthy environment in society from moral and spiritual perspectives, it also gives an extensive strategy to be applied by the concerned teachers for imparting informal Islamic education effectively. Certain contents of informal Islamic education outlined here, if implemented, surely will function as effective means for building the stable society. This type of society is an immense need in the age of the moral and spiritual crises. Such a society can help the Muslims live harmoniously and peacefully, and achieve salvation from Allah in the life hereafter. Besides, the society will inspire the non-Muslims towards the teachings of Islam and play a very significant role to remove the misgivings about Islam. 


\section{Informal Islamic Education and its Role in Human Resource Development in Society}

\section{References:}

1. Siddiquee , Bakhtiar Hossain, Education: An Islamic Perspective, University Grants Commission: Islamabad, 1986, p. 47, in Iqbal, Zafar, Teachers' Training: The Islamic Perspective. The Institute of Policy Studies, Islamabad and International Institute of Islamic Thought, Pakistan, Islamabad 1996, p.49.

2. $\quad$ Ibid., p.49.

3. Ashraf, Syed Ali, (ed) Islamic Education Quarterly, Vol.1, No.1, The World Centre for Islamic Education and King Abdulaziz University, Makkah, October,1981, p.22.

4. Ibid., pp.22-23.

5. Iqbal, Zafar, Teachers' Training: The Islamic Perspective, The Institute of Policy Studies, Islamabad and International Institute of Islamic Thought, Pakistan, Islamabad,1996, p.51.

6. Ibid., p.50.

7. Ibid.,p.50.

8. Al- Taftazani, Abul Wafa Al-Guneimi, "Islamic Education: Its Principles and Aims", Muslim Education, vol. 4, no.1, Islamic Academy, Cambridge, 1986, p.67 in Iqbal, Zafar, Teachers' Training: The Islamic Perspective, The Institute of Policy Studies, Islamabad and International Institute of Islamic Thought, Pakistan, Islamabad, 1996 p.50.

9. Sarker, A.M. and Ahmad, S.U., Essay on "Non-formal Education", Dolphin Book House, Dhaka, 1999, p.221.

10. Ali, M. Shamsher, "Objectives and Techniques of Imparting Islamic Education through Informal Channels", Paper read in the prelenary session of the Training Workshop for the guidance of Counsellors of Islamic Education in Informal Education held on 29 April to 3 May 2003 sponsored by ISESCO and organised by BNCU at BIAM, Dhaka.

11. Hajaltom, Basher M.O., Islamic Moral Education, Umm Al-Qura University: Makkah, KSA, 1982, p.103.

12. Ali, M. Shamsher, "Objectives and Techniques of Imparting Islamic Education throughI Informal Channels", Paper read in the prelenary session of the Training Workshop for the guidance of Counsellors of Islamic Education in Informal Education held on 29 April to 3 May 2003 sponsored by ISESCO and organised by BNCU at BIAM, Dhaka.

13. Iqbal, Zafar, Teachers' Training: The Islamic Perspective. The Institute of Policy Studies, Islamabad and International Institute of Islamic Thought, Pakistan, Islamabad,1996, p.78.

14. Hajaltom, Basher M.O., Islamic Moral Education, Umm Al-Qura University: Makkah, KSA, 1982, p107.

15. Iqbal, Zafar, Teachers' Training: The Islamic Perspective. The Institute of Policy Studies, Islamabad and International Institute of Islamic Thought, Pakistan, Islamabad,1996,p. 88.

16. Siddiquee, Bakhtiar Hossain, Education: An Islamic Perspective ,Islamabad: University Grants Commission, 1986, p. 40, in Iqbal, Zafar, Teachers' Training: The Islamic Perspective, The Institute of Policy Studies, Islamabad and International Institute of Islamic Thought, Pakistan, Islamabad, 1996, p.89.

17. Iqbal, Zafar, Teachers' Training: The Islamic Perspective, The Institute of Policy Studies, Islamabad and International Institute of Islamic Thought Pakistan, Islamabad, 1996, ( subtitles are drawn), pp.89- 96.

18. Ibid., p.97. 


\section{IIUC Studies, Vol. 3}

19. Noor, Abdun, "Education and Human Development", The Islamic Quarterly, Vol. 45, Issue 4, 2001, The Islamic Cultural Centre \& Central Mosque, London, p.336.

20. Ali, M. Shamsher, "CommunicativeTeaching in Informal Islamic Education", Paper read in the Training Workshop for the guidance Counsellors of Islamic Education in Informal Education held on 29 April to 3 May 2003 sponsored by ISESCO and organised by BNCU at BIAM, Dhaka.

21. Ali, Syed Ashraf, "Communicative Teaching in Informal Islamic Education", Paper read in the Training Workshop for the guidance Counsellors of Islamic Education in Informal Education held on 29 April to 3 May 2003 sponsored by ISESCO and organized by BNCU at BIAM, Dhaka.

22. Ismail,Shaikh Malik, "Towards Effective Instruction”, Al Jumuah, Vol. 15, Issue 11, JhulQidah 1424 H., London: Al Muntada Al- Islami, London, pp.41-42.

23. Ibid., pp. 42-43.

24. Ali, M.Shamsher, "Technique of Teaching and Learning in Informal Islamic Educaton", Paper read in the Training Workshop for the guidance Counsellors of Islamic Education in Informal Education held on 29 April to 3 May 2003 sponsored by ISESCO and organised by BNCU at BIAM, Dhaka. 